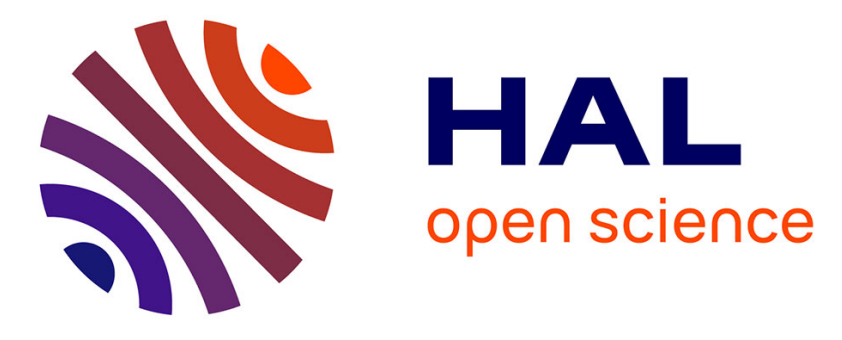

\title{
New bio-based phosphorylated chitosan/alginate protective coatings on aluminum alloy obtained by the LbL technique
}

Clément Coquery, Federico Carosio, Claire Negrell, Nicolas Causse, Nadine Pébère, Ghislain David

\section{To cite this version:}

Clément Coquery, Federico Carosio, Claire Negrell, Nicolas Causse, Nadine Pébère, et al.. New biobased phosphorylated chitosan/alginate protective coatings on aluminum alloy obtained by the LbL technique. Surfaces and Interfaces, 2019, 16, pp.59-66. 10.1016/j.surfin.2019.04.010 . hal-02120603

\section{HAL Id: hal-02120603 \\ https://hal.science/hal-02120603}

Submitted on 22 Oct 2021

HAL is a multi-disciplinary open access archive for the deposit and dissemination of scientific research documents, whether they are published or not. The documents may come from teaching and research institutions in France or abroad, or from public or private research centers.
L'archive ouverte pluridisciplinaire HAL, est destinée au dépôt et à la diffusion de documents scientifiques de niveau recherche, publiés ou non, émanant des établissements d'enseignement et de recherche français ou étrangers, des laboratoires publics ou privés.

\section{(c) (1) $\$$}

Distributed under a Creative Commons Attribution - NonCommerciall 4.0 International 


\section{New bio-based phosphorylated chitosan/alginate}

\section{protective coatings on aluminum alloy obtained by}

\section{the LbL technique}

Clément Coquery $^{a, b}$, Federico Carosio $^{c}$, Claire Negrell ${ }^{a}$, Nicolas Causséb ${ }^{b}$, Nadine Pébère $^{b}$, Ghislain David ${ }^{*}$

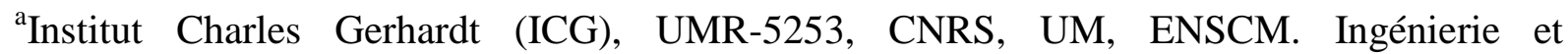
Architectures Macromoléculaires (IAM), 240 avenue Emile Jeanbrau, 34296 Montpellier Cedex 5, France

${ }^{\mathrm{b}}$ CIRIMAT, Université de Toulouse, CNRS, INPT, ENSIACET, 4 allée Emile Monso, CS 44362, 31030 Toulouse Cedex 4, France

${ }^{c}$ Dipartimento di Scienza Applicata e Technologia, Politecnico di Torino, sede di Alessandria, Viale Teresa Michel 5, 15121 Alessandria, Italy

* Corr espond ing author .

E-ma il : ghislain.david@enscm.fr 


\begin{abstract}
Bio-based coat ings were obtained by the layer-bylayer (LbL) technique from a native chit osan $\left(\mathrm{M}_{\mathrm{w}} \mathrm{3}\right.$ 30,000 $\left.\mathrm{g} \mathrm{mol}^{-1}\right)$ or fromt wo synthesized phosphorylat ed chit osan of differ ent

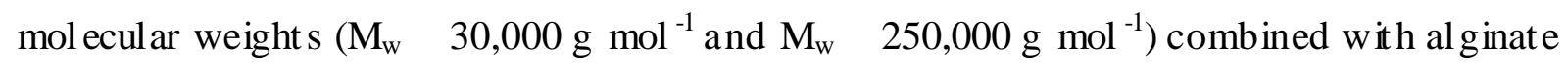
and used for corrosion protect ion of an aluminum alloy (AA) 3003. Fir st , the LbL growth was monit ored by Four ier transfor m infrared spectroscopy on sil icon wafers. Cross-sect ions of Si wafers were examined by scanning el ectron microscopy allowing the films thickness to be measured. With the nat ive chitosan and in the presence of 10 bilayer s, the LbLthickness was about $200 \mathrm{~nm}$, whereas it was about $300 \mathrm{~nm}$ with the phosphorylated chitosan of low molecular weight and about $500 \mathrm{~nm}$ with the phosphorylated chitosan of high molecular weight. Then, the bio-based coat ings were deposit ed on the AA3003 by the LbL technique and their protective propert ies were evaluated by el ectrochemical impedance spectroscopy (EIS) dur ing immer sion in a $0.1 \mathrm{M} \mathrm{Na}_{2} \mathrm{SO}_{4}$ sol ut ion. It was shown that the three LbL coat ings improved the corrosion resistance of the AA3003. The resistance values, extracted at low frequency on the impedance diagra ms were attr ibut ed to the r esistance of the al uminu m oxide layer $\left(R_{o x}\right)$. The $R_{o x}$ values were at least two orders of magnitude higher for the coated samples $\left(10^{8} \Omega \mathrm{cm}^{2}\right)$ compared to the uncoated one $\left(510^{5} \Omega \mathrm{cm}^{2}\right)$. There was no significant difference between the different LbL coatings, which mainly acted by decreasing the act ive surface ar ea and have a 1 imit ed barrier effect.
\end{abstract}

Keywords

Phosphorylated chitosan ; Layer-by tayer assembly ; Coat ing ; Al uminum alloy ;

El ectrochemical impedance spectroscopy 


\section{Introduction}

The Layer-by-Layer (LbL) deposition represents an innovative and interesting alternative for the development of coatings for several applications such as flame retardants[1,2], electrochromic[3] applications, medical and bioapplications[4,5] but also nanoengineering[6,7]. The LbL technique is attractive mainly due to an easy integration of functional materials, treatment under ambient conditions (room temperature and atmospheric pressure) and ecological characteristics (solvent is mainly water and concentrations of solutions/dispersions are less than 1 wt. \%). LbL coatings are elaborated on a substrate by the sequential adsorption of chemical species based on one or more functional interactions. The most common interaction is provided by the electrostatic attraction[8,9]; indeed, the alternative adsorption of opposites charged polyelectrolytes allows the accumulation of structured laminated or strongly interpenetrated coatings[10]. Among available polyelectrolytes, polysaccharides can be rather good candidates to perform fully bio-based LbL systems, due to their low toxicity, biodegradability and natural availability[11]. Chitosan is the second most abundant bio-based polysaccharide on the earth, after cellulose, and is the major component in crustaceans, exoskeletons, fungi or insects[12]. Chitosan is a linear copolymer of glucosamine and $\mathrm{N}$-acetyl-glucosamine, obtained from chitin by alkaline deacetylation[13] or from enzymatic pathway[14]. It is biocompatible[15], non-toxic[16], antibacterial[17] and can be used to form films[18,19]. Alginate is a linear polysaccharide formed from two monomers in different proportions bound in $\beta-(1-4)$ : mannuronate and guluronate[20]. Alginate-chitosan system has already been used for various applications such as, membrane manufacturing[21], biomedical[22] and drug delivery[23]. Lawrie et al. studied the interactions between alginate and chitosan using FTIR and XPS analyses[24]. The interest to prepare LbL coatings for corrosion protection purpose is to build a physical barrier with strong interactions between each layer, thus preventing the penetration of aggressive species 
through the coating towards the metal substrate. To our knowledge, only Gao et al. reported the use of chitosan and alginate as component for a LbL coating for the protection of a magnesium implant in a biological fluid[22]. In their study, the coating was elaborated by spin-coating including forty cycles, each containing four layers: the first layer was the anionic alginate (ALG), the second one was the cationic mechano-growth factor MGF (i.e. a cationic polypeptide polymer), the third one was again the anionic ALG and the fourth one was the cationic chitosan. The resulting multi-layer coating was $18 \mu \mathrm{m}$ thick. The authors found that the corrosion rate of the coated $\mathrm{Mg}$ alloy was slightly decreased by comparison with the uncoated sample, despite the substantial LbL coating thickness.

Phosphonic acid-containing polymers have numerous potential applications as they exhibit attractive properties in term of adhesion[25] and are of interest in corrosion inhibition[26,27]. Furthermore, the phosphorous-containing molecules or polymers can act as adhesion promoters for different substrates such as aluminum, zinc and steel[28,29]. In our previous work, it was shown that the use of chitosan bearing phosphonic acid groups decreased the corrosion rate of a carbon steel by comparison with native chitosan[30]. Some LbL systems, based on phosphorylated chitosan have already been published, aiming at providing new protective coatings for fireproof applications[31]. To our knowledge, no alginatephosphorylated chitosan system was so far developed through the LbL technique in order to develop protective coatings.

In the present work, elaboration and characterization of LbL coatings from alginate and native or phosphorylated chitosan of two different molecular weights $\left(30,000 \mathrm{~g} \mathrm{~mol}^{-1}\right.$ and $250,000 \mathrm{~g}$ $\mathrm{mol}^{-1}$ ) were first investigated on Si wafers, commonly used as model surfaces for the LbL characterization, in particular to follow the LbL growth. In this study, the LbL growth was monitored by Fourier transform infrared (FTIR) spectroscopy and the films thickness was determined by scanning electron microscopy (SEM). Then, the LbL coatings were deposited 
on aluminum (AA3003) plates and characterized by electrochemical impedance spectroscopy (EIS). The impedance of the coated samples was measured as a function of the exposure time to a $0.1 \mathrm{M} \mathrm{Na}_{2} \mathrm{SO}_{4}$ solution.

\section{Experimental}

\subsection{Materials}

Native chitosan, high molecular weight $\left(\mathrm{M}_{\mathrm{w}} \approx 250,000 \mathrm{~g} \mathrm{~mol}^{-1}\right.$, degree of deacetylation: $92 \%$, henceforth called Nchitosan250) and medium molecular weight $\left(\mathrm{M}_{\mathrm{w}} \approx 30,000 \mathrm{~g} \mathrm{~mol}^{-1}\right.$, degree of deacetylation: $92 \%$, henceforth called Nchitosan30) were purchased from Glentham Life Sciences society. Phosphorylated chitosan from Nchitosan30 (henceforth called Pchitosan30) and from Nchitosan250 (henceforth called Pchitosan250) were synthesized according to our previous study[30]. Sodium alginate (from brown algae, $M_{w}=140,000 \mathrm{~g} \cdot \mathrm{mol}^{-1}$ ) was purchased from Aldrich. Acetic acid (> $99.7 \%$, Aldrich) was used as received. Deionized water was obtained from a Millipore Milli-Q purification system. The LbL coatings were deposited onto an aluminum alloy 3003 (AA3003). Its chemical composition in weight percent was: $\mathrm{Cu}=0.05 ; \mathrm{Fe}=0.7 ; \mathrm{Mn}=1.5 ; \mathrm{Si}=0.6 ; \mathrm{Zn}=0.1$ and $\mathrm{Al}$ to balance. The specimens consisted of $127 \mathrm{~mm}$ x $76 \mathrm{~mm}$ x $0.8 \mathrm{~mm}$ plates, purchased from Labomat. Before the deposition of the LbL coatings, the AA3003 samples were successively cleaned with acetone and ethanol and dried for $10 \mathrm{~min}$ at $80^{\circ} \mathrm{C}$.

\subsection{LbL assembly}

The procedure for obtaining the LbL fil ms was independent of the substrates (Si wafer and AA3003). The negat ively charged sol ut ion was prepared with sodium alginate $(1 \mathrm{wt} . \%, \mathrm{pH}=$ 5), while the posit ively charged solut ion was prepared from either Nchitosan30, Pchitosan30 or Pchit osan250 (1 wt.\%). Increasing the concentrat ion of chitosan in solut ion should reduce the time per deposition step but, in the present work, concentration higher than $1 \mathrm{wt} . \%$ 
increased the viscosity of the solution, particularly for the Nchitosan[32]. The different chit osans were dissolved in deionised water and the $\mathrm{pH}$ was adjust ed to 5 by addit ion of either acet ic acid for the Nchitosan or $\mathrm{NaOH}$ for the Pchitosan. Both substrates ( $\mathrm{Si}$ wafer and AA3003) were first dipped in a 0.1 wt. \% BPEI (Branched PolyEthyleneImine) solution, leading to cationic charges onto their surfaces[33]. The layers were then deposited by alternating immersion of the sample during $1 \mathrm{~min}$ in the solution containing the anionic polymer (alginate) and then, during $1 \mathrm{~min}$ in the solution containing the cat ionic polymer. Aft er each immer sion st ep, the sa mpl e was washed with deionised wat er and dr ied with war m air. Up to 10 layers (BL) were deposited. Only Nchitosan30 was used to develop the LbL coat ing because the Nchitosan 250 was too viscous (even at low concentration) to enable LbL assembly. Thus, only three LbL systems were investigated: alginate/Nchitosan30, alginate/Pchitosan 30 and alg inate/Pchit osan 250 .

\subsection{Analytical characterizations}

Zeta potentials (ZP) were measured for $2 \mathrm{~g} \mathrm{~L}^{-1}$ of Nchitosan30 and Pchitosan30 using a Zetasizer 2000 system (Malvern Instruments LtD). The $\mathrm{pH}$ of the Nchitosan solution was adjusted at $\mathrm{pH}=2$ by adding acetic acid solution $(1 \mathrm{M})$. The increase of $\mathrm{pH}$ was controlled by addition of $\mathrm{NaOH}(1 \mathrm{M})$. The applied voltage for driving electrodes of the capillary electrophoresis cell was $10 \mathrm{~V}$. The Zetasizer 2000 cell was rinsed with deionized water before each experiment. All experiments were conducted at $25^{\circ} \mathrm{C}$.

Coating growth was monitored using a Frontier Perkin-Elmer FTIR spectrophotometer (16 scans and $4 \mathrm{~cm}^{-1}$ resolution) equipped with a Ge/Ge crystal (depth of penetration $0.65 \mu \mathrm{m}$ ).

Cross-sections of the deposited coatings on $\mathrm{Si}$ wafers were imaged using a field-emission scanning electron microscope (FE-SEM, Zeiss Merlin 4248). Prior to FE-SEM observations Si cross-sections were chromium coated. A FEI Quanta 450 scanning electron microscope 
(SEM) was used for the surface characterization of the AA3003. Semi-quantitative analysis was performed by energy dispersive X-ray spectroscopy (EDX) with a Ge detector (EDS Bruker Quantax SDD). EDX analyses were performed over different locations on the AA3003 surface before and after exposure to the $\mathrm{Na}_{2} \mathrm{SO}_{4}$ solution.

\subsection{Electrochemical characterizations}

Electrochemical impedance measurements were performed in a classical three-electrode cell in which the coated LbL sample served as working electrode. A cylindrical glass tube was clamped onto the coated AA3003 plate, exposing a surface area of $14.9 \mathrm{~cm}^{2}$ and filled with 60 $\mathrm{mL}$ of a $0.1 \mathrm{M} \mathrm{Na}_{2} \mathrm{SO}_{4}$ solution. A platinum electrode with a large surface area and a mercury sulfate electrode (MSE) in a saturated potassium sulfate solution with $E_{M S E}=0.64 \mathrm{~V} / \mathrm{SHE}$ were used as counter and reference electrodes, respectively. They were placed on the top of the glass tube by means of an electrode holder. The impedance diagrams were obtained for various immersion times (from $1 \mathrm{~h}$ to $48 \mathrm{~h}$ ) to the $\mathrm{Na}_{2} \mathrm{SO}_{4}$ solution. It is generally accepted that $\mathrm{SO}_{4}{ }^{2-}$ are less aggressive than $\mathrm{Cl}^{-}$. In the present study, a less aggressive electrolyte was chosen to minimize the corrosion of the AA3003 substrate, thus allowing the LbL films to be compared according to their composition and thickness.

Electrochemical impedance measurements were carried out using a Biologic VSP apparatus. The diagrams were obtained under potentiostatic conditions, at the open circuit potential, over a frequency range of $65 \mathrm{kHz}$ to $10 \mathrm{mHz}$ with 8 points per decade, using a $30 \mathrm{mV}$ peak-to-peak sinusoidal voltage perturbation. The experiments were performed at room temperature $(22 \pm 3$ $\left.{ }^{\circ} \mathrm{C}\right)$. The linearity of the system was checked by varying the signal amplitude. $30 \mathrm{mV}$ was a good compromise to obtain the impedance diagrams without any dispersion.

\section{Results and discussion}




\subsection{Determination of phosphorylated chitosan global charge vs $\mathrm{pH}$}

In our previous study ${ }^{30}$, native chitosan, high molecular weight $\left(\mathrm{M}_{\mathrm{w}} \approx 250,000 \mathrm{~g} \mathrm{~mol}^{-1}\right.$, called Nchitosan250) and medium molecular weight $\left(\mathrm{M}_{\mathrm{w}} \approx 30,000 \mathrm{~g} \mathrm{~mol}^{-1}\right.$, called Nchitosan30) were modified by grafting phosphonic acid functions onto primary amines. About $20 \%$ of the primary amines were modified for each chitosan. In the present study, high and medium Mw phosphorylated chitosan (Pchitosan250 and Pchitosan30, respectively) were used to build the LbL coatings. According to the $\mathrm{pH}$ value, phosphonic acid moieties can be anionic whereas amine groups can be cationic. Thus, due to the partial grafting of phosphonic moieties onto amine functions, the global charge of the functionalized chitosan must be evaluated. Zeta potential (ZP) measurements of the Nchitosan and Pchitosan solutions were performed to determine the global charge of the polymers. The ZP values of the Nchitosan30 and Pchitosan30, obtained at different $\mathrm{pH}$ values ranging from 2 to 10, are reported in Fig. 1.

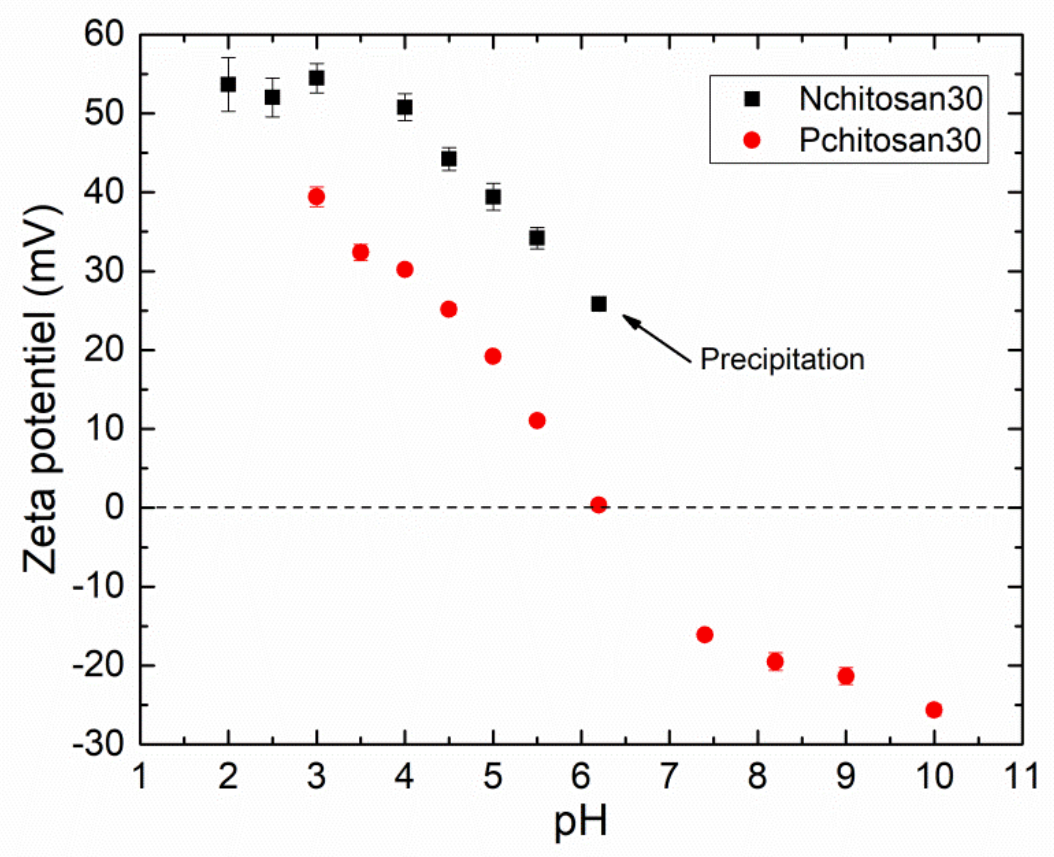

Figure 1. ZP of Nchitosan30 and Pchitosan30 as a function of $\mathrm{pH}$. 
For the Nchitosan30, it can be seen that the $\mathrm{ZP}$ values are always positive in the $\mathrm{pH}$ range from 2 to 6.5 , confirming that it is a cationic polymer. The ionic charge of the polymer is due to the amine protonation for $\mathrm{pH}$ values lower than $6.5[34]$. For $\mathrm{pH}>6.5$, the Nchitosan is no longer soluble and precipitates in the solution.

In the case of Pchitosan30, the $\mathrm{ZP}$ values are positive for $\mathrm{pH}<6$ and negative for $\mathrm{pH}>6$. Unlike Nchitosan30, Pchitosan30 remains soluble over the entire $\mathrm{pH}$ range due to the presence of phosphonic acid functions. At $\mathrm{pH}<6$, Pchitosan30 is a polymer with a global cationic behavior because most of the amine functions are protonated (Fig. 2), like Nchitosan. For Pchitosan30, about 20-25\% of the amine functions carry a bisphosphonic acid moieties. At $\mathrm{pH}=5$, only one $\mathrm{P}-\mathrm{OH}$ group is deprotonated to form $\mathrm{P}-\mathrm{O}-\left(\mathrm{pKa}_{1}=2.6\right.$ and $\mathrm{pKa}_{2}=$ 6.7[35]), which thus decreases the $\mathrm{ZP}(\mathrm{ZP}=20 \pm 2 \mathrm{mV})$ as compared to Nchitosan $(\mathrm{ZP}=39 \pm$ $2 \mathrm{mV}$ ) but still remains positive. For $\mathrm{pH}>6$, Pchitosan is anionic. It is to be noted that Pchitosan250 solution showed a similar cationic behavior than that of the Pchitosan30 (not shown here). In the present study, the $\mathrm{pH}$ of the Nchitosan and Pchitosan solutions was fixed at 5 to ensure a cationic behavior for both solutions, even for the alginate solution since carboxylic acid groups are deprotonated at this $\mathrm{pH}(\mathrm{pKa}=3.5[36])$. Moreover, the same $\mathrm{pH}$ value was used for all the solutions to avoid modification of the AA3003 surface during the formation of the LbL coatings[37].

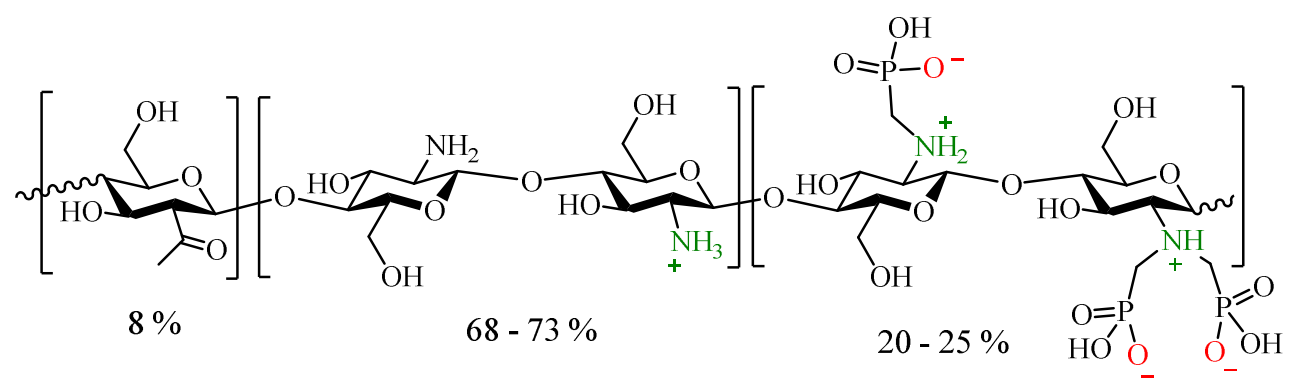

Figure 2. Structure of stat ist ical Pchitosan 30 at $\mathrm{pH}=5$, containing $8 \%$ of acetylated mo iet ies, $68-73 \%$ of a mine mo iet ies and $20-25 \%$ of a mino-bis phonic acid mo iet ies. 


\subsection{Development of the LbL coatings on silicon wafers}

Three LbL systems were investigated: alginate/Nchitosan30, alginate/Pchitosan30 and alginate/Pchitosan250. FTIR spectrum was recorded for each bilayer and for each system. Fig. 3 shows, as an example, the evolution of absorbance for the alginate/Pchitosan30 system, according to the bilayers number up to10 bilayers.

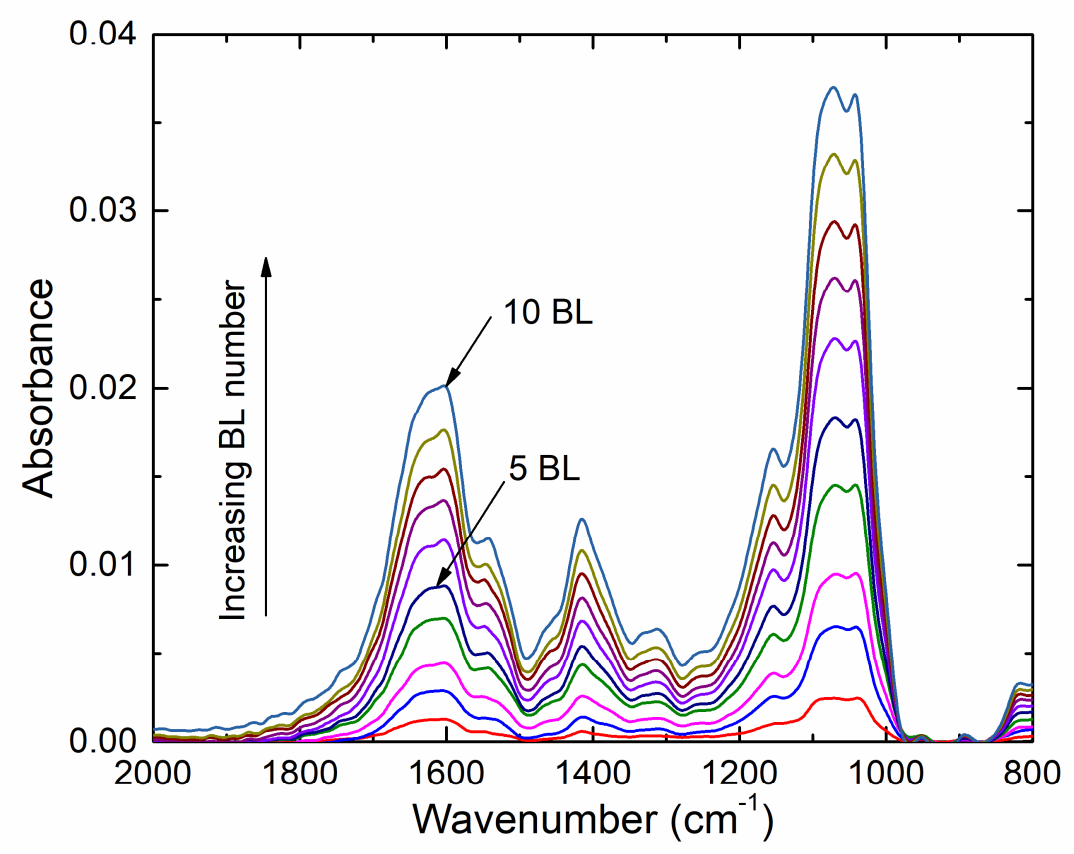

Figure 3. FTIR spectra as a function of the bilayers (BL) number for the alginate/Pchitosan30 system.

From Fig. 3, it is possible to depict vibrations of both alginate and Pchitosan 30. For the alginate, the vibrations of the $\mathrm{COO}^{-}$carboxylate group[24] are clearly visible: asymmetric elongation at $1594 \mathrm{~cm}^{-1}$ and symmetrical el ongation at $1408 \mathrm{~cm}^{-1}$, respect ively. For the Pchit osan 30, the two vibrations at 1656 and $1589 \mathrm{~cm}^{-1}$ are attribut ed to amide I and to N-H bending [38] of $\mathrm{NH}_{2}$, respect ively. The ma in phosphonate band is al so observed at $1190 \mathrm{~cm}^{-1}$ due to the elongat ion of the $\mathrm{P}=\mathrm{O}$ double bond[39]. The presence of this peak is due to the 
partial hydrolysis of phosphonic esters to phosphonic acids during the synthesis of Pchitosan 30. From Fig. 3, the absorbance at $1090 \mathrm{~cm}^{-1}$ (i.e. maximum wavel ength corresponding to $\mathrm{C}-\mathrm{O}-\mathrm{C}$ bonds for both the alginate and the chitosan) was used to follow the fil m growth. The absorbance was plotted as a function of the bilayers number for the three LbL systems (Fig. 4). A 1 inear increase of the absorbance is observed for the three systems. For $10 \mathrm{bil}$ ayer s, the absorbance recorded for the alginate/Pchit osan 250 coat ing is the highest . The absorbance for the alginate/Pchitosan30 is slightly higher than that of alginate/Nchitosan 30. From this r esult, it can be concluded that the phosphorylat ion of nat ive chit osan sl ightly increased the a mount of deposit ed chitosan.

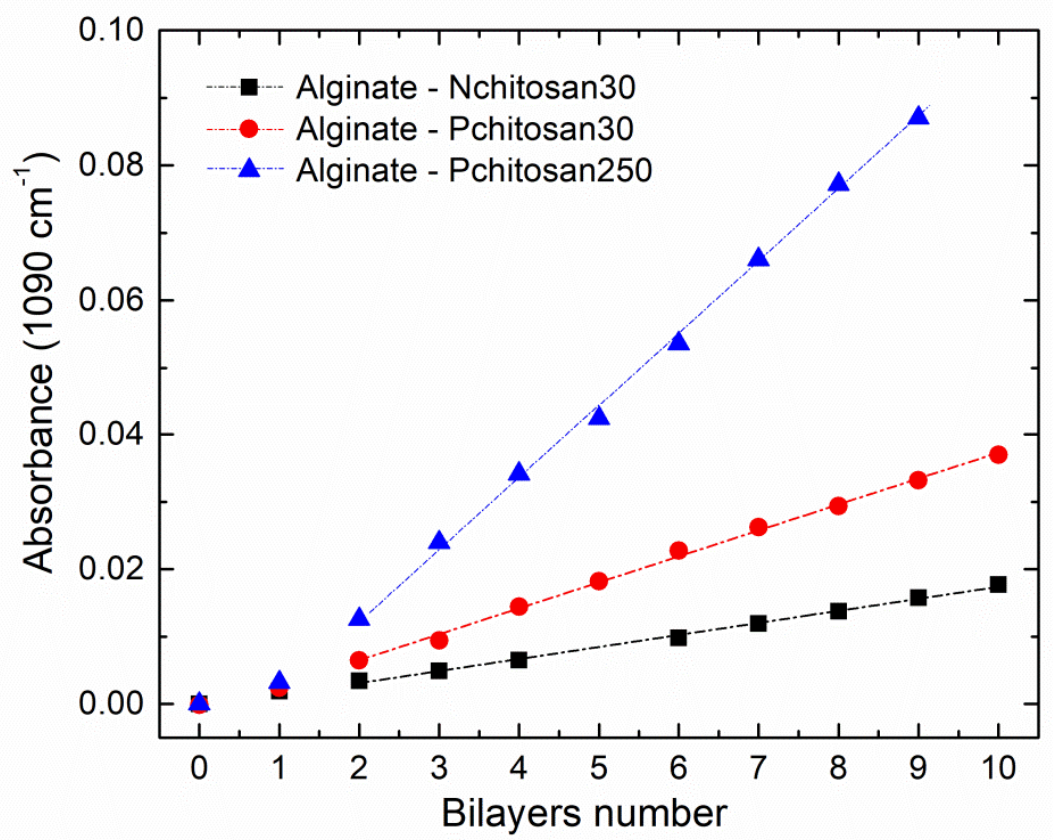

Figure 4. Absor bance at $1090 \mathrm{~cm}^{-1}$ as a funct ion of the number of bilayer s for the three $\mathrm{LbL}$ syst ems.

FE-SEM cross-sect ion observat ions of the wafer/chit osan fil ms were perfor med for the three LbL coat ings (Fig. 5). The micrographs show that the thr ee coat ings have a un ifor mt hickness. The alginate/Nchitosan30 and the alginate/Pchitosan30 LBL coat ings have relat ively simil ar 
thickness values, i.e. $200 \mathrm{~nm}$ and $300 \mathrm{~nm}$, r espectively. A higher thickness was mea sured for the alginate-Pchitosan 250 coat ing, ar ound $500 \mathrm{~nm}$, in good agr eement with the FTIR results.
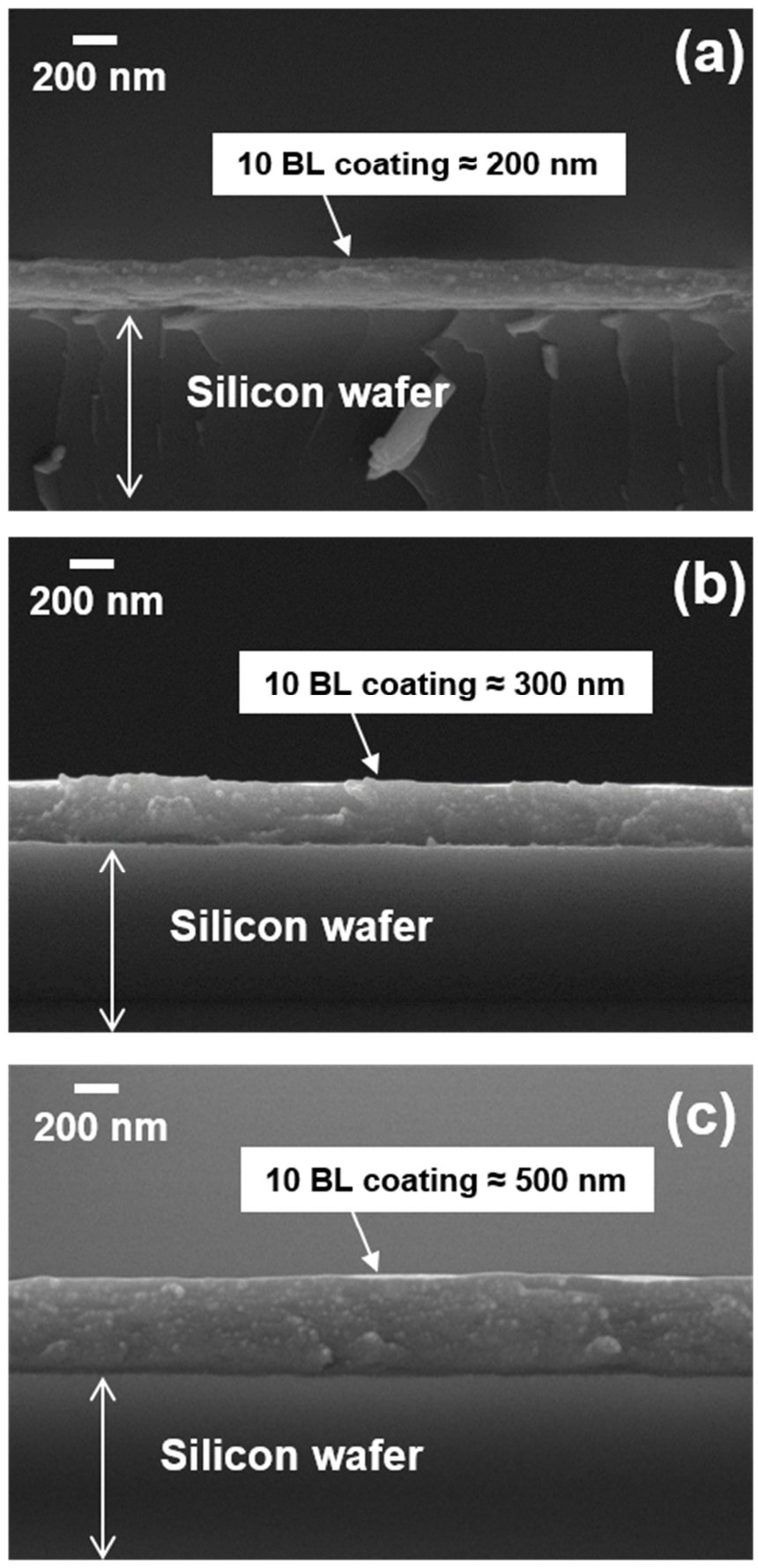

Figure 5. FE-SEM micrographs of the cross-sect ions of Si wafer s coated with 10 bilayer s for : (a ) al ginat e/Nchit osan30, (b) al ginate/Pch it osan30 and (c) al ginate/Pchit osan 250.

Thus, it can be concluded that the use of phosphorylated chitosan with a high molecular weight led to a higher thickness for the LbL coatings. At $\mathrm{pH}=5$, Nchitosan30 is a cat ionic 
polymer, which will show 1 inear confor mation when assembled with the anionic alginate layer. On the other way, we showed that at $\mathrm{pH}=5$, Pchitosan 30 was zwitterionic (i.e. with maximum $20-25 \%$ of anionic charge and maximum $68-73 \%$ of cat ionic charge), which might lead to some coil forms due to intramolecular interactions between cationic and anionic charges. Consequently, when associated to the anionic alginate layer, a higher a mount of Pchit osan 30 was deposited compared to Nchitosan30. Mor eover, an increase of chitosan Mw, i.e. from 30 to $250 \mathrm{~kg} \mathrm{~mol}^{-1}$, has an influence on the $\mathrm{LbL}$ growth. The thickening of the layer for Pchitosan 250 can be explained by a greater entanglement of the polymer chains. As a consequence, a higher amount of Pchitosan 250 was deposited, as compared to Nchitosan or Pchit osan 30 .

\subsection{Evaluation of corrosion protection of the AA3003 by the LbL coatings}

EIS measurements were performed for the AA3003 LbL coated samples as well as for the uncoated AA3003 sample. For each system, the impedance diagrams were obtained consecutively for various immersion times $(3 \mathrm{~h}, 12 \mathrm{~h}, 24 \mathrm{~h}$ and $48 \mathrm{~h})$ in a $0.1 \mathrm{M} \mathrm{Na}_{2} \mathrm{SO}_{4}$ solution. As an example, Fig. 6 shows the impedance diagrams obtained for the AA3003 coated with alginate/Nchitosan30 (10 BL). Independently of the immersion time, the diagrams are almost identical. They show a capacitive behavior and it can be observed that the impedance modulus and the phase angle slightly decrease at low frequency when the immersion time increases (more noticeable on the phase angle). 

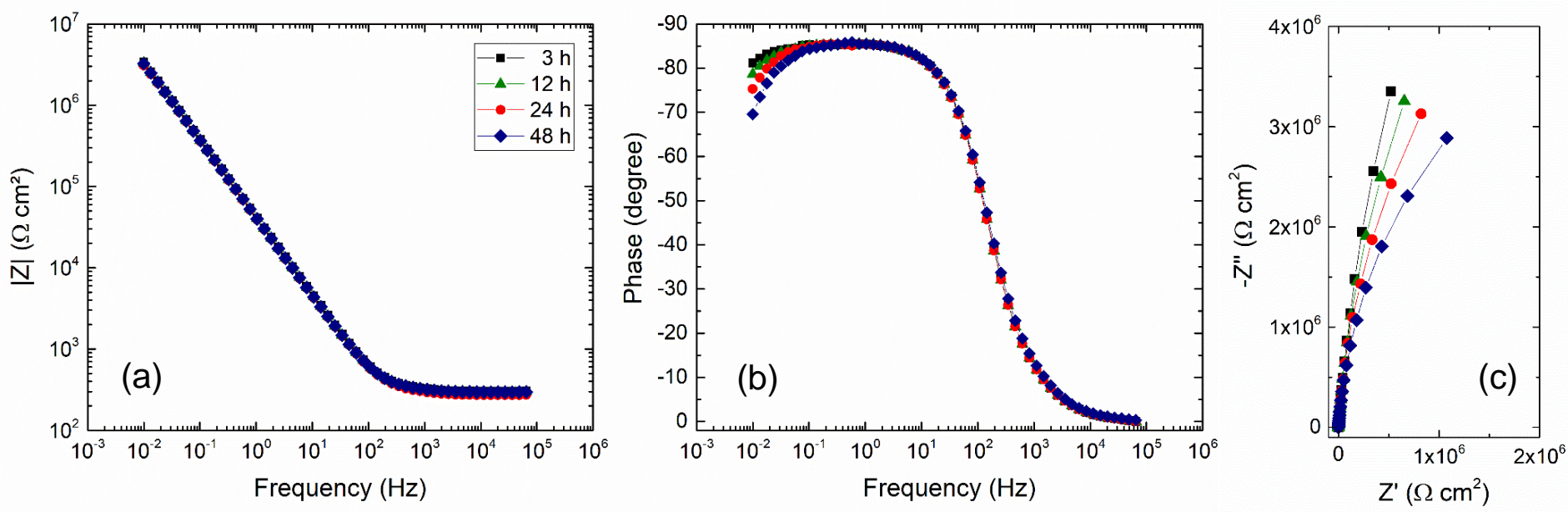

Figure 6. Electrochemical impedance diagrams obtained at $E_{c o r r}$ for the AA3003 coated with the alginate-Nchitosan30 (10 bilayers) for different immersion times in $0.1 \mathrm{M} \mathrm{Na}_{2} \mathrm{SO}_{4}$ solution in Bode (impedance modulus (a) and phase angle (b)) and Nyquist (c) coordinate.

Then, for comparison, the impedance diagrams obtained after $48 \mathrm{~h}$ of immersion for the three LBL coatings and for the uncoated sample are presented in Fig. 7.
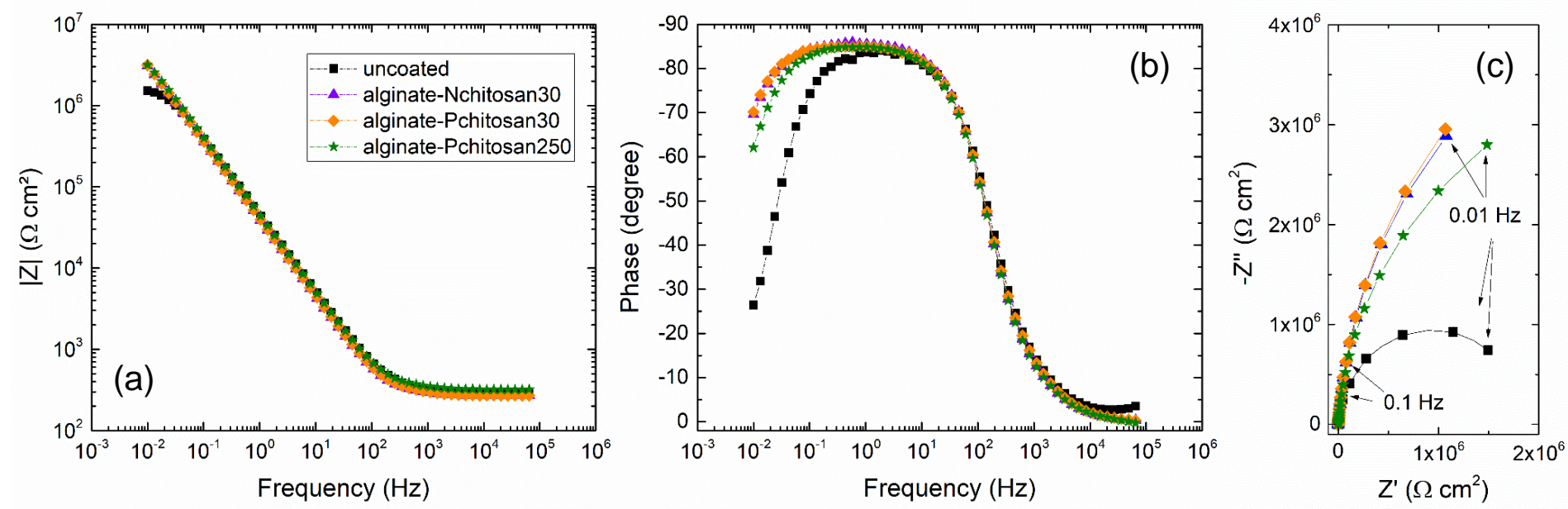

Figure 7. Electrochemical impedance diagrams obtained at $E_{c o r r}$ after $48 \mathrm{~h}$ of immersion in $0.1 \mathrm{M} \mathrm{Na}_{2} \mathrm{SO}_{4}$ solution for the uncoated AA3003 and the three LbL coatings (10 BL) in Bode (impedance modulus (a) and phase angle (b)) and Nyquist (c) coordinates. 
The diagrams for the three LbL coat ings are quite comparable indicat ing similar corrosion protect ion performance for the different systems. It can be underl ined that the open circuit pot ent ial (OCP) for the different LbL systems deposit ed on the AA3003 was relat ively simil ar $(-0.90 \pm 0.5 \mathrm{~V} / \mathrm{MSE})$ in agreement with the impedance results. The OCP was sl ightly shifted towards more negat ive value by compar ison with the uncoated AA3003 sampl e $(\mathrm{OCP}=-0.85$ $\pm 0.2 \mathrm{~V} / \mathrm{MSE})$.

Despite the presence of the LbL fil ms, visual ized on the Si wafers (Fig. 5), the impedance diagrams are constituted by a single time constant. The presence of an additional time constant in the high frequency range, character izing a fil m effect is not observed, as might be expect ed and as already observed for very thin organic fil ms $(20 \mathrm{~nm})$ for med on a carbon steel surface[40]. The impedance response of the LbL coatings pointed out that the barrier propert ies were low, probably due to a porous structure of the coat ings. Thus, with and without the LbL coat ings, the impedance diagrams character ize the aluminum ox ide fil $\mathrm{m}$ on the AA3003 surface. As can be seen in Fig. 6 and Fig. 7, the phase angle is always lower than $-90^{\circ}$ (maximum value around $-87^{\circ}$ ) which indicates a non-ideal behavior of the AA3003 / LbL coating interface. From the impedance diagrams, some parameters can be extracted: the oxide film resistance $\left(R_{o x}\right)$ and a constant phase element $(C P E)$, which accounts for the nonideal behavior of the interface. The impedance of the CPE is given by Eq. 1:

$$
Z_{C P E}=\frac{1}{(j \omega)^{\alpha} Q}
$$

With $\omega=2 \pi f$ and where $\alpha$ is related to the angle of rotation of a purely capacitive line on the complex plane plots and $Q$ is a constant expressed in $\alpha^{-1} \mathrm{~cm}^{-2} \mathrm{~s}^{\alpha}$.

In the present work, equivalent electrical circuits were not used to extract impedance parameters because all the parameters can be graphically determined [41]. The $R_{o x}$ values 
were obtained from the extrapolation at low frequency of the impedance modulus (when the phase angle decreases towards 0 ). The $\alpha$ parameter can be determined by plotting the logarithm of the imaginary part of the impedance $\left(Z_{j}\right)$ with respect to the logarithm of the frequency (Eq. 2). $Q$ is expressed as a function of $\alpha$ and impedance data (Eq. 3):

$$
\begin{gathered}
\alpha=\frac{d \log \left(-Z_{j}\right)}{\operatorname{dlog}(f)} \\
Q=\sin \left(\frac{\alpha \pi}{2}\right) \frac{-1}{Z_{j}(f)(2 \pi f)^{\alpha}}
\end{gathered}
$$

The $\alpha$ and $Q$ values are reported in Table 1 for the different systems and for various immer sion $\mathrm{t}$ imes.

Table 1. Parameters obtained from the impedance data for the uncoated AA3003 and the three LbL coatings (10 BL) after different exposure times to $0.1 \mathrm{M} \mathrm{Na}_{2} \mathrm{SO}_{4}$ solution.

\begin{tabular}{|c|c|c|c|}
\hline \multirow{3}{*}{ Sample } & $\begin{array}{c}\text { Immersion time } \\
(\mathrm{h})\end{array}$ & $\alpha$ & $Q$ \\
& & & $\left(\mathrm{M}^{-1} \mathrm{~cm}^{-2} \mathrm{~s}^{\alpha}\right)$ \\
\hline \multirow{3}{*}{ Uncoated AA3003 } & 3 & 0.94 & $3.2 \pm 0.1$ \\
\cline { 2 - 4 } & 12 & 0.94 & $3.6 \pm 0.2$ \\
\cline { 2 - 4 } & 24 & 0.94 & $4.2 \pm 0.2$ \\
\hline \multirow{3}{*}{$\begin{array}{c}\text { AA3003/Alginate- } \\
\text { Nchitosan30 }\end{array}$} & 48 & 0.94 & $4.3 \pm 0.2$ \\
\cline { 2 - 4 } & 3 & 0.94 & $4.2 \pm 0.2$ \\
\cline { 2 - 4 } & 24 & 0.94 & $4.3 \pm 0.2$ \\
\hline \multirow{3}{*}{$\begin{array}{c}\text { AA3003/Alginate- } \\
\text { Pchitosan30 }\end{array}$} & 38 & 0.94 & $4.3 \pm 0.1$ \\
\cline { 2 - 4 } & 12 & 0.94 & $4.5 \pm 0.1$ \\
\cline { 2 - 4 } & 24 & 0.93 & $3.7 \pm 0.1$ \\
\cline { 2 - 4 } & 48 & 0.94 & $4.3 \pm 0.1$ \\
\hline \multirow{3}{*}{ AA3003/Alginate- } & 3 & 0.94 & $3.7 \pm 0.1$ \\
\cline { 2 - 4 } Pchitosan250 & 12 & 0.94 & $3.9 \pm 0.1$ \\
\cline { 2 - 4 } & 24 & 0.94 & $4.0 \pm 0.1$ \\
\cline { 2 - 4 } & 48 & & $4.2 \pm 0.1$ \\
\hline
\end{tabular}


The var iat ion of $R_{o x}$ as a funct ion of the ex posure time to the $\mathrm{Na}_{2} \mathrm{SO}_{4}$ sol ut ion is shown in Fig. 8.

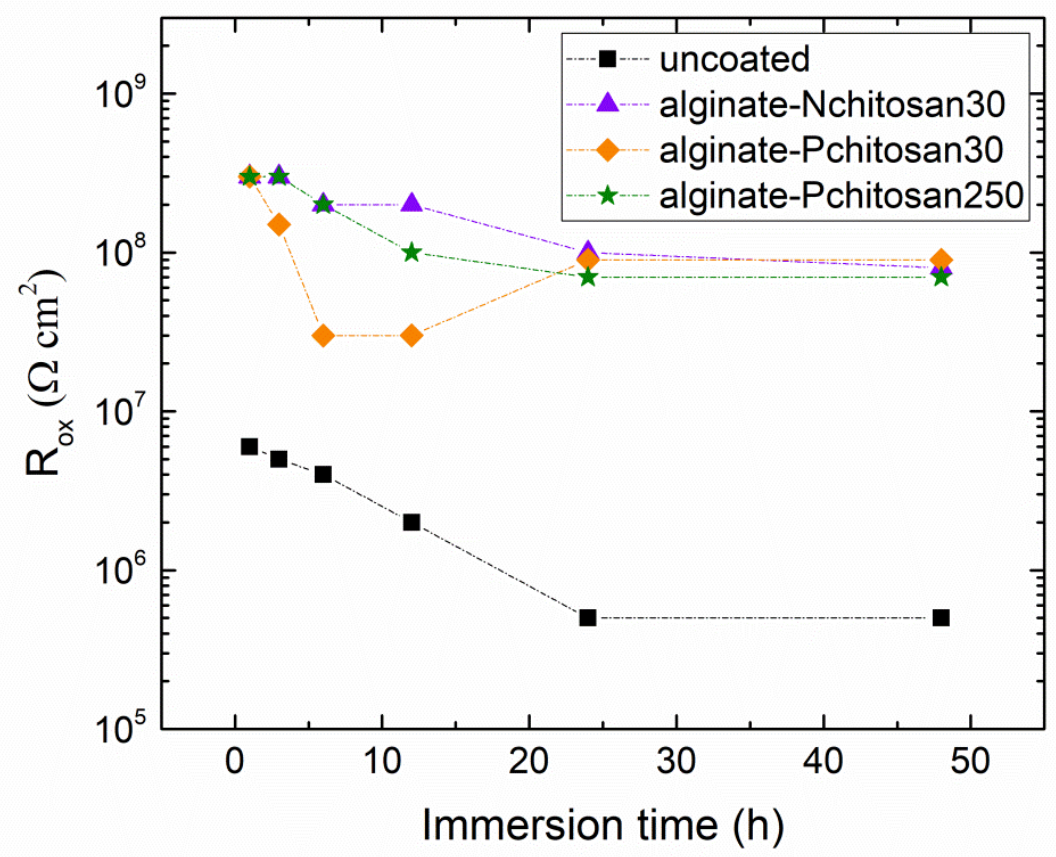

Figure 8. $R_{o x}$ as a funct ion of the immer sion $\mathrm{t}$ ime in $0.1 \mathrm{M} \mathrm{Na}{ }_{2} \mathrm{SO}_{4}$ sol ut ion for the uncoated AA3003 and for the three LbL coat ings (10 BL).

For the uncoated AA3003, the $R_{o x}$ values decreases with increasing immersion time. This might be attributed to the corrosion process which induces a local $\mathrm{pH}$ increase on the aluminum surface due to the cathod ic react ion (oxygen reduct ion)[42]. As a consequence, the nat ive aluminum oxide tends to dissolve (chemical reaction) when the immersion time increases. This assumption is in agreement with the var iat ion of $Q v s$ the immersion time (Table 1). The $Q$ value, related to the oxide film capacitance, increases with time indicating a decrease of the oxide film thickness.

For the three LbL coatings, $R_{o x}$ sl ightly decreases dur ing the first hours of ex posure to the el ectrolyte and then remains constant. After $48 \mathrm{~h}$ of immer sion, the $R_{o x}$ values are similar for the three systems and they are at least two orders of magnitude higher for the coat ed sa mpl es 
$\left(10^{8} \Omega \mathrm{cm}^{2}\right)$ by compar ison with the uncoat ed sample $\left(510^{5} \Omega \mathrm{cm}^{2}\right)$, suggest ing a decrease of the act ive surface area by the coatings, since there is no modification of the $\alpha$ and $Q$ parameters. This last result indicates that the chitosan phosphorylation did not improve the corrosion protect ion of the AA3003 by compar ison with the nat ive chitosan although the LbL coat ings thickness was higher, in particular for the alginate-Pchitosan250, as observed by SEM on the Si wafers (Fig. 5).

SEM-EDX analysis was performed with a low energy (5 keV) to compare the layer composit ion before (Fig. 9a and 9a') and after $48 \mathrm{~h}$ of immer sion in the $\mathrm{Na}_{2} \mathrm{SO}_{4}$ sol ut ion (Fig . $9 \mathrm{~b}$ and $\left.9 \mathrm{~b}^{\prime}\right)$. The analysis was showed here for the alginate-Pchitosan $250 \mathrm{LbL}$ coat ing.
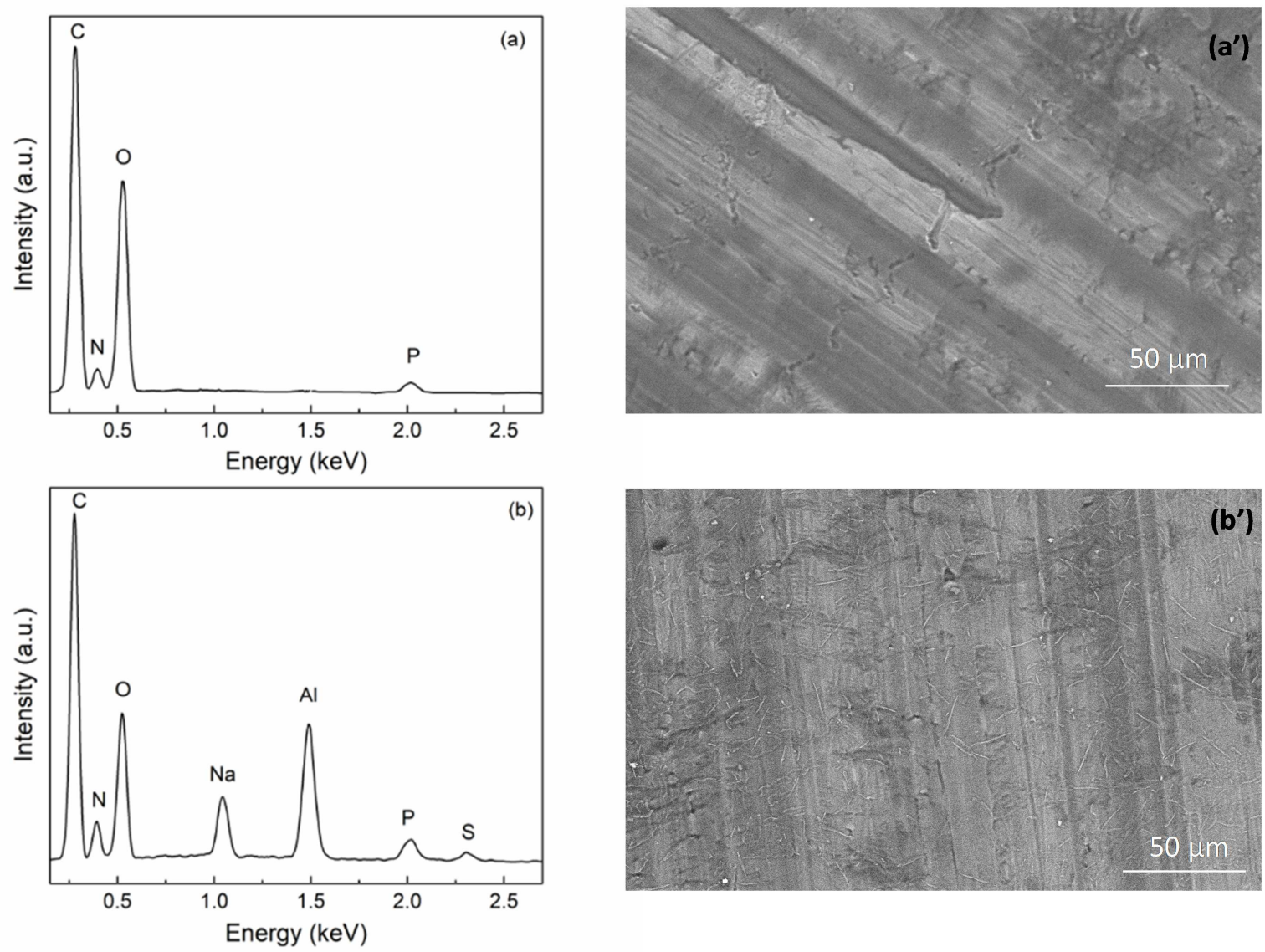

Figure 9. EDX analysis and SEM observations for the alginate-Pchitosan250 LbL coating: (a) and (a') before immersion and (b) and (b') after $48 \mathrm{~h}$ of immersion in the $\mathrm{Na}_{2} \mathrm{SO}_{4} 0.1 \mathrm{M}$ solution. 
Before immersion (Fig. 9a and 9a'), the analysis reveals the presence of C, N, O and P peaks confir ming the presence of the al ginate and the Pchitosan on the AA3003 surface. It is worthy to note that the $\mathrm{Al}$ peak is not detected, which might indicate the presence of a un if or $\mathrm{m} \mathrm{LbL}$ coat ing, as shown by the SEM observat ions on the Si wafers (Fig. 5). After immer sion in the $\mathrm{Na}_{2} \mathrm{SO}_{4}$ solut ion (Fig. 9b and 9b'), the C, N, O and P peaks are st ill visible, showing that the LbL coat ing is al ways present on the AA3003 surface. After immer sion, Al is det ected which suggest s that the LbL coat ing was da maged dur ing the immer sion. In addition, the $\mathrm{Na}$ and $\mathrm{S}$ peaks are observed, indicat ing the presence of sodium sulfate (fromt he el ectrolyte) in the LbL coat ing. The EDX analyses conf ir med that a LBL coat ing was for med on the AA3003 surface but the barr ier effect wasl imit ed (penetration of the el ectrolyte and presence of the Al peak). EIS data and EDX analysis revealed that chitosan/alginate LBL coatings allowed the AA3003 surface to be protected through a barrier effect, which decreased the active surface area in contact with the electrolyte. Nevertheless, during exposure to the $\mathrm{Na}_{2} \mathrm{SO}_{4}$ solution, the barrier effect was limited, as shown from the impedance results, despite the presence of the coating, as proved by the EDX analysis. The limited barrier effect could be attributed to a swelling of the LBL coating, and to a partial solubility of the Nchitosan and Pchitosan in the aqueous solution.

Furthermore, the phosphonic acid moiet ies grafted onto chitosan allowed higher coating thicknesses to be reached compared to native chit osan (Fig. 5), but simil ar el ectrochemical behaviors were observed (Fig. 8 and Table 1). One way to improve the barrier propert ies of such coat ings might be to perfor m an additional crosst inking, after the LbL deposition. Or, the bilayer should be more hydrophobic. In this case, chitosan chemical modif icat ion should be done prior to perfor $m$ the LbLdeposition.

\section{Conclusions}


Layer-by-Layer coatings comprising alginate and either unmodified or phosphorylated chitosan at different molecular weights were evaluated for their potential to reduce the corrosion of an aluminum alloy 3003. First, the growing rate of the LbL coatings was determined on Si wafers by measuring the IR absorbance according to the bilayers number. The system containing phosphorylated chitosan appeared to grow faster than that with the unmodified chitosan. FE-SEM observations revealed coating thicknesses between $200 \mathrm{~nm}$ and $500 \mathrm{~nm}$ according to the type of chitosan. It was found that the use of phosphorylated chitosan at 1 wt. $\%$ and high molecular weight $\left(250,000 \mathrm{~g} \mathrm{~mol}^{-1}\right)$ promoted the deposition of thicker coatings. The corrosion protection of the AA3003 was assessed by electrochemical impedance spectroscopy in a $\mathrm{Na}_{2} \mathrm{SO}_{4} 0.1 \mathrm{M}$ solution. It was shown that the three LbL systems afforded similar corrosion protection by reducing the active surface area by comparison with the uncoated sample. Even if the EDX analysis has confirmed the presence of the coating on the metal surface, the EIS measurements revealed a limited barrier effect.

\section{AUTHOR INFORMATION}

\section{Corresponding Author}

*Ghislain DAVID: Ghislain.david @enscm.fr

\section{Author Contributions}

The manuscript was written through contributions of all authors. All authors have given approval to the final version of the manuscript. All authors contributed equally.

\section{Funding Sources}

This work financially supported by the Direction Générale de l'Armement (DGA). The authors gratefully acknowledge the DGA for this support. 


\section{REFERENCES}

(1) G. Malucell i, F. Bosco, J. Al ongi, F. Carosio, A. Di Blasio, C. Mollea, F. Cutt ica, A. Casale, Biomacromolecules as novel green flame retardant systems for text iles: an overview, RSC Adv . 4 (2014) 46024-46039.

(2) G. Malucelli, Layer -by-Layer nanostructured assembl ies for the fire protection of fabrics, Mater. Lett. 166 (2016) 339-342.

(3) S. I. Cordoba de Torr esi, J. R. Mart ins Net o, M. Vidott i, F. Huguen in, Electrochromic Mater ials and Devices, Layer -by tayer assembly of el ectrochromic mater als: on the efficient method for immobil isat ion of nanomater ial s, 2015, 12, 337-361.

(4) V. N. Gunjkar, S. L. Patwekar, S. P. Dhage, St imul i responsive layer by layer selfassembly a novel a pproachs in current drug del ivery:review, World J. Phar m. Phar m. Sci. 4 (2015) 216-238.

(5) D. Volodkin, A. Skirtach, H. Moehwald, Bioa ppl icat ions of 1 ight -sensitive polymer fil ms and capsules assembled using the layer-by layer technique, Polym. Int . 61 (2012) 673-679.

(6) N. Est illore, W. Knoll, R. Advincula, Ionic Interactions in Natural and Synthet ic Macromol ecules., 2012, 17, Funct ional layer by tayer polyel ectrolyt es: assembly strat egies, character izat ion, and sel ect ed a ppl icat ions, 643-682.

(7) D. V. Andreeva, E. V. Skorb, Multilayer smart coat ings for corrosion protect ion of al uminium alloys and st eel, Woodhead Publ . Ser . Met . Surf. Eng. 64 (2014) 307-327.

(8) G. Decher, Fuzzy Nanoassembl ies: Toward Layered Polymer ic Mult icomposites, Science 277 (1997) 1232-1237.

(9) R. K. Il er, Mult ilayers of colloidal particles, Journal of Colloid and Int erface Science 21 (1966) 569-594.

(10) P. Berndt, K. Kur ihara, T. Kunitake, Adsor pt ion of poly(styrenesulfonate) onto an ammonium monolayer on mica: a surface forces study, Langmu ir 8 (1992) 24862490.

(11) S. A. Umoren, U. M. Eduok, Appl ication of carbohydrate polymers as corrosion inhibit ors for metal substrates in different media: A review., Carbohydrate Polymers 140 (2016) 314-341.

(12) S. K. Kim, Chit in, Chitosan, Ol igosaccharides and Their Der ivat ives: Biological Act iv it ies and Appl icat ions, 1st ed. CRC Press, Boca Rat on ed., 2010.

(13) R. A. A. Muzzarell i, Chit in, Perga mon Press, Oxford ed., 1977.

(14) I. Tsigos, A. Mart inou, D. Kafetzopoulos, V. Bour iot is, Chit in deacetylases: new, ver sat il et ool s in biot echnology, Tr ends in Biot echnology 18 (2000) 305-312.

(15) P. J. VandeVord, H. W. T. Matthew, S. P. DeSil va, L. Mayton, B. Wu, P. H. Wool ey, Evaluation of the biocompat ibil ity of a chitosan scaffold in mice, J. Biomed. Mater. Res. 59 (2002) 585-590.

(16) M. Rinaudo, Chit in and chit osan: propert ies and a ppl icat ions, Prog. Polym. Sci. 31 (2006) 603-632.

(17) S. Tokura, K. Ueno, S. Miyazaki, N. Nishi, Molecular Weight Dependent Ant imicrobial Activity by Chitosan, New Macromolecular Architecture and Funct ions, Spr inger Berl in Heidel berg ed., 1996.

(18) P. K. Dutta, J. Dutta, V. S. Tr ipathi, Chit in and chitosan: Chemistry, propert ies and appl icat ions, Journal of Scient if ic \& Industrial Research 63 (2004) 20-31.

(19) J. Nunthanid, S. Puttipipatkhachorn, K. Ya ma moto, G. E. Peck, Physical propert ies and molecular behavior of chitosan fil ms, Drug Dev Ind Phar m. 27 (2001) 143-157.

(20) H. Grasdal en, High-field, 1H-NMR spectroscopy of al ginate: sequent ial structure and linkage confor mat ions, Carbohydrate Research. 118 (1983) 255-260. 
(21) S. G. Car idade, C. Monge, F. Gil de, T. Boudou, J. F. Mano, C. Picart, Free-Standing Pol yel ectrolyte Membranes Made of Chit osan and Alginate, Biomacromol ecul es 14 (2013) 1653-1660.

(22) H. Gao, M. Zhang, J. Zhao, L. Gao, M. Li, In vitro and in vivo degradat ion and mechanical propert ies of ZEK100 magnesium alloy coated with al ginate, chit osan and mechano-growth fact or , Mat er ials Science \& Engineer ing. C, Mat er ial s for Biological Appl icat ions 63 (2016) 450-461.

(23) M. George, T. E. Abraham, Polyionic hydrocolloids for the intest inal del ivery of prot ein drugs: al ginate and chitosan--a review, Journal of Controlled Rel ease: Official Journal of the Controlled Rel ease Societ y 114 (2006) 1-14.

(24) G. Lawr ie, I. Keen, B. Drew, A. Chandl er-Templ e, L. Rintoul, P. Fr eder icks, L. Gr øndahl, Int eractions between Alginate and Chitosan Biopolymers Characterized Using FTIR and XPS, Biomacromol ecul es 8 (2007) 2533-2541.

(25) C. Brondino, B. Bout evin, J.-P. Par isi, J. Schrynemacker s, Adhesive propert ies onto galvanized steel plates of grafted poly(vinyl idene fluoride) powders with phos phonated acrylates, J. Appl . Polym. Sci. 72 (1999) 611-620.

(26) E. Kál mán, F. H. Kármán, J. Tel egdi, B. Várhegyi, J. Balla, T. Kiss, Inhibit ion efficiency of $\mathrm{N}$-containing carboxyl ic and carboxy-phosphonic acids, Corrosion Science 35 (1993) 1477-1482.

(27) X. H. To, N. Pebere, N. Pela prat, B. Bout evin, Y. Her vaud, A corrosion-pr ot ect ive fil $\mathrm{m}$ formed on a carbon steel by an organic phosphonate, Corrosion Science 39 (1997) 1925-1934.

(28) I. Maege, E. Jaehne, A. Henke, H.-J. P. Adl er, C. Bra m, C. Jung, M. Stratmann, Selfassembl ing adhesion promoters for corrosion resistant metal polymer interfaces, Progress in Organic Coating (1998) 1-12.

(29) F. Millet, R. Auvergne, S. Ca illol, G. David, A. Manser i, N. Pébère, Improvement of corrosion protection of steel by incor poration of a new phosphonated fatty acid in a phosphorus-containing polymer coating obtained by UV cur ing, Progress in Organic Coat ing 77 (2014) 285-291.

(30) C. Coquery, C. Negrell, N. Caussé, N. Pébère, G. David, Synthesis of new high mol ecular weight phosphorylated chitosans for improving corrosion protect ion., Pure and Appl ied Chemistry 913 (2019) 509-521.

(31) L. Liu, Y. Pan, Z. Wang, Y. Hou, Z. Gui, Y. Hu, Layer-by-Layer Assembly of Hypophosphorous Acid-Modified Chitosan Based Coating for Fame-Retardant Pol yester-Cotton Bl ends, Industrial \& Eng ineer ing Chemistry Research 5634 (2017) 9429-9436.

(32) F. Carosio, J. Al ongi, Ultra-Fast Layer-by-Layer Approach for Deposit ing Fame Retardant Coatings on Fexible PU Foams within Seconds, ACS Appl ied Materials \& Int erfaces 810 (2016) 6315-6319.

(33) F. Carosio, C. Negr ell-Guirao, J. Al ongi, G. David, G. Ca mino, All -poly mer Layer by Layer coat ing as efficient solut ion to polyurethane foam fla me retardancy, European Pol ymer Journal 70 (2015) 94-103.

(34) V. Vassileva, E. M. Georgiev, K. Troev, D. M. Roundhill, Dealkylation of phos phorus-containing alkyla mmonium salts for med by the interact ion of phosphonic, methanephosphonic and phosphor ic acid esters with diamines, Phosphorus, Sulfur Sil icon Relat.Elem. 92 (1994) 101-107.

(35) P. G. Fal ireas, C. Negrell, G. David, Synthesis and Aqueous Solut ion Propert ies of an Amino Bisphosphonate Methacrylate Homopolymer via RAFT Polymerization, Polymers 10 (2018) 711-723. 
(36) K. I. Draget, G. Skjåk Br æk, O. Smidsr ød, Al ginic acid gel s: the effect of alginate chemical composit ion and mol ecular weight, Carbohydrate Polymers 25 (1994) 3138.

(37) G. Laufer, C. Kirkland, A. A. Ca in, J. C. Gr unlan, Cay-Chitosan Nanobrick Walls: Compl et el y Renewable Gas Barr ier and Hame-Retardant Nanocoat ings, ACS Appl ied Materials \& Int erfaces 43 (2012) 1643-1649.

(38) B. Smitha, S. Sr idhar, A. A. Khan, Chitosan-sodium alginate polyion compl exes as fuel cell membranes, Eur. Polym. J. 41 (2005) 1859-1866.

(39) N. Illy, G. Couture, R. Auvergne, S. Caillol, G. David, B. Bout evin, New prospect s for the synthesis of $\mathrm{N}$-alkyl phosphonate/phosphonic acid-bear ing ol igo-chitosan, RSC Adv. 4 (2014) 24042-24052.

(40) J. Baux, N. Causse, J. Esvan, S. Delaunay, J. Tir eau, M. Roy, D. You, N. Pebere, Impedance analysis of fil $\mathrm{m}$-for ming a mines for the corrosion protection of a carbon st eel, E ectrochim. Acta 283 (2018) 699-707.

(41) M. Orazema, N. Pébère, B. Tr ibollet, Enhanced Graphical Representation of El ectrochemical Impedance Data, J. E ectrochem. Soc. 1534 (2006) B129-B136.

(42) J. B. Jorcin, C. Bl anc, N. Pébère, B. Tr ibollet, V. Vivier, Galvanic Coupl ing Bet ween Pure Copper and Pure Aluminum : Ex per imental Approach and Mathematical Model, J. El ectrochem. Soc. 1551 (2008) C46-C51. 


\section{Gra phical abstract}

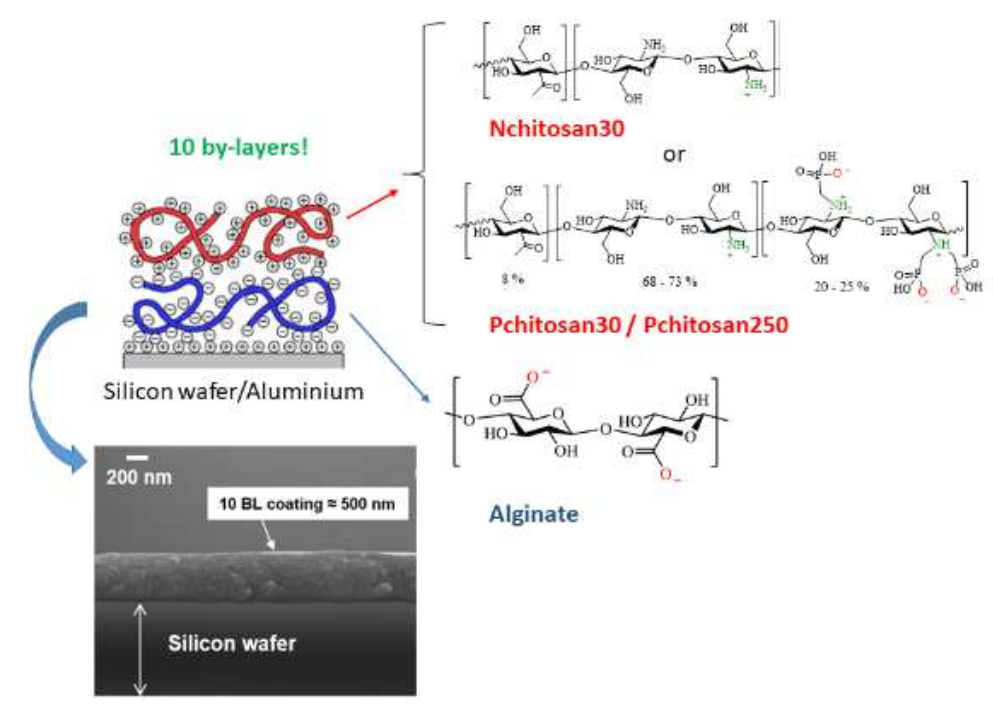

